\title{
Pengaruh Pemasaran Berbasis Pengalaman, Efikasi Diri, dan Kepercayaan terhadap Niat Beli Kembali Layanan Bus Premium
}

\author{
Firman Fauzi", Armelia Levana \\ Program Studi Manajemen Fakultas Ekonomi \& Bisnis Universitas Mercu Buana \\ Jalan Meruya Selatan No. 1, Kembangan, Jakarta Barat, Indonesia 11650 \\ *Email: firman.fauzi@mercubuana.ac.id
}

\begin{abstract}
Artikel Info ABSTRAK
Dikirim:

28 Januari 2020

Revisi:

14 Februari 2020

Diterima:

23 Maret 2020

Penelitian ini bertujuan untuk menganalisis pengaruh Pemasaran berbasis Pengalaman (Experiental Marketting), Efikasi Diri (Self Efficacy) dan Kepercayaan (Trust) terhadap Niat Beli Kembali (Repurchase Intention) pada Layanan Bus Premium Royaltrans. Data yang digunakan adalah data primer yang disusun menggunakan kuesioner, analisa data menggunakan Structural positif dan Equation Model (SEM) dengan menggunakan Partial Least Square (smartPLS 3.0). Objek penelitian ini adalah para pelanggan Layanan Bus Premium Royaltrans di wilayah Bekasi dengan 4 rute yakni pelanggan Bekasi Barat - Blok M, Bekasi Barat - Kuningan, Bekasi Timur - Kalideres, Bekasi Timur - Tebet Jatibening Kuningan yang menggunakan Layanan Bus Premium Royaltrans. Sampel yang dipergunakan adalah sebanyak 160 responden pengguna Layanan Bus Premium Royaltrans melalui teknik purposive sampling. Hasil dari penelitian menunjukan bahwa terdapat pengaruh positif dan signifikan antara Experiential Marketing terhadap Repurchase Intention, Self Efficacy terhadap Repurchase Intention dan Trust terhadap Repurchase Intention. Dari hasil penelitian ini menunjukkan variabel independen (Experiential Marketing), (Self Efficacy) dan (Trust) terhadap variabel dependen (Repurchase Intention) memberikan nilai R-square sebesar 0.788 yang dapat di interpretasikan bahwa variabel konstruk Experiential Marketing, Self Efficacy dan Trust sebesar 78,8\% sedangkan 21,2\% dijelaskan oleh variabel lain di luar yang akan diteliti.
\end{abstract}

Kata Kunci: Pengalaman berbasis Pemasaran, Efikasi Diri, Kepercayaan, Niat Beli Kembali, Konsumen, Layanan Bus

\section{Effects of Experiential Marketing, Self-efficacy and Trust on Repurchase Intention in Premium Bus Services}

\begin{abstract}
This study aims to analyze the effect of Experiential Marketing, Self Efficacy, and Trust in Repurchase Intentions in Royaltrans Premium Bus Services. The data used are primary data compiled using a questionnaire, data analysis using a positive Structural and Equation Model (SEM) using Partial Least Square (smartPLS 3.0). This study's object is Royaltrans Premium Bus Service customers in the Bekasi region with four customer routes West Bekasi - Blok M, West Bekasi - Kuningan, East Bekasi - Kalideres, East Bekasi - Tebet Jatibening - Kuningan using Royaltrans Premium Bus Service. The sample used amounted to 160 respondents using Royaltrans Premium Bus Service through a purposive sampling technique. The study results indicate a positive and significant effect between Experiential Marketing on Repurchase Intention, Self Efficacy on Repurchase Intention, and Trust on Repurchase Intention. From the results of this study indicate the independent variable (Experiential Marketing), (Self Efficacy) and (Trust) to the dependent variable (Repurchase Intention) gives an R-square value of 0.788 which can be interpreted as the construct marketing variable Experiential Marketing, Self Efficacy and Trust of 78, 8\%. In comparison, $21.2 \%$ are discussed by other variables beyond those to be submitted.
\end{abstract}

Keyword: Experiential Marketing, Self Efficacy, Trust, Repurchase Intention, Customers, Premium Buses

Cara Sitasi :

Fauzi, F., \& Levana, A. (2020). Pengaruh Pemasaran Berbasis Pengalaman, Efikasi Diri, dan Kepercayaan terhadap Niat Beli Kembali Layanan Bus Premium. Jurnal Ilmiah Manajemen dan Bisnis, 21(1), 45-59. https://doi.org/ 10.30596/jimb.v21i1.4027. 


\section{Jurnal Ilmiah Manajemen dan Bisnis}

ISSN 1693-7619 (Print) I ISSN 2580-4170 (Online)

\section{PENDAHULUAN}

Sepuluh tahun terakhir Provinsi DKI Jakarta mengalami perkembangan yang sangat pesat di sektor perdagangan, industri, pariwisata, dan pengembangan layanan transportasi publik. Berdasarkan data Badan Pusat Statistik (BPS), pada tahun 2017 jumlah penduduk Ibukota mencapai sekitar 10,37 juta jiwa dan terus bertambah setiap tahunnya memberikan efek bertambahnya jumlah kendaraan bermotor meningkat secara signifikan dan membuat kemacetan. Permasalahan kemacetan lalulintas merupakan bagian permasalahan transportasi, yaitu terlalu besarnya kebutuhan akan pergerakan dibandingkan dengan prasarana transportasi yang tersedia. Suatu cara memecahkan masalah tersebut adalah membangun prasarana sesuai dengan kebutuhan, mengurangi pergerakan, dan gabungan keduanya. Kemacetan selalu menjadi polemik di wilayah DKI Jakarta dan sekitarnya (Jabodetabek), dikarenakan masyarakat menggunakan kendaraan pribadi untuk melakukan berpergian ke kantor. Dari hasil survei mengatakan bahwa perbandingan kendaraan pribadi dengan angkutan umum sangatlah berbeda jauh berdasarkan hasil dari DataJakarta.go.id meyatakan bahwa:

Tabel 1. Perbandingan Jumlah Kendaraan Pribadi dan Angkutan Umum

\begin{tabular}{ccc}
\hline Tahun & Kendaraan Pribadi & Angkutan Umum \\
\hline 2008 & $6,264,393$ & 88,409 \\
2009 & $6,688,913$ & 91,455 \\
2010 & $7,340,783$ & 89,978 \\
2011 & $7,979,983$ & 92,351 \\
2012 & $8,452,843$ & 103,815 \\
2013 & $9,257,801$ & 104,147 \\
2014 & $9,902,917$ & 112,724 \\
\hline
\end{tabular}

Sumber: Data diolah dari Data.Jakarta.go.id, 2014

Bila dilihat dari Tabel 1, peningkatan kendaraan pribadi dari tahun 2008 sampai dengan 2014 mengalami kenaikan yang cukup signifikan tak sebanding dengan jumlah angkutan umum yang tersedia di
Ibukota. Terlihat pada tahun 2014 Jumlah kendaraan pribadi 9.902.917 sedangkan angkutan umum hanya 112.724, hal ini dapat memicu terjadinya kemacetan yang terjadi di Ibukota.

Bahwa sebagian besar warga Bekasi bergerak menuju ke DKI Jakarta dengan angka mencapai 359.531 Penduduk. Bila mengacu pada data BPS Kota Bekasi pada tahun 2014 jumlah warga Bekasi sebanyak 2.829.000 Penduduk, maka bila dipersentasikan terdapat $12,71 \%$ warga Bekasi bergerak beraktivitas menuju ke wilayah DKI Jakarta. Hal ini menunjukkan bahwa antusias warga Bekasi untuk berkerja di Jakarta cukup signifikan.

Hasil tersebut, tidak hanya mendorong adanya kemacetan namun beberapa akibat lainnya yakni, warga Bekasi selain tidak hanya memadati jalan, tetapi juga memadati pada transportasi publik seperti kereta rel listrik, busway, dan sarana transportasi umum lainnya. Sehingga bila merujuk pada tabel 1 dan tabel 2 menunjukkan kesenjangan yang cukup signifikan dalam pemenuhan Transportasi Publik antar kota.

Pemerintah menerapkan aturan baru ganjil dan genap untuk mobil yang melintas di pintu tol Bekasi Barat dan Bekasi Timur menuju Jakarta. Pemberlakukan ganjil genap tol Bekasi Barat dan Bekasi Timur bukan hanya untuk mengurangi kepadatan kendaraan di ruas tol Jakarta-Cikampek dan beliau mengungkapkan tujuan lebih besar dari penerapan aturan ini yaitu bagaimana mendidik masyarakat untuk beralih dari mobil pribadi ke angkutan umum.

(diakses dari https://www.liputan6.com, 2018).

Dengan adanya penurunan jumlah kendaraan dari program Ganjil - Genap ini, maka perlu ada perubahan pada Transportasi Publik, Transportasi Publik bertaraf premium juga sangat dibutuhkan untuk menarik dan mendorong minat masyarakat golongan kelas atas (High Class) untuk beralih ke 
transportasi yang nyaman dan aman serta dengan fasilitas pendukung lainnya. Wacana yang ditargetkan pemerintah yakni mendidik masyarakat untuk beralih ke transportasi umum, maka Kementerian Perhubungan berkerjasama dengan Badan Pengelola Transportasi Transjabodetabek (BPTJ) dan beberapa perusahaan transportasi dalam menyiapkan armada Bus Premium Transjabodetabek untuk menarik minat beli kembali layanan transportasi umum yang nyaman, aman dan tepat waktu. Perusahaan Transportasi mulai menyiapkan armada Bus Premium seperti wajah lama sebelumnya Perum Pengangkutan Penumpang Djakarta (PPD), Mayasari Bakti dan PT Big Bird Pustaka dan pendatang baru yakni armada Bus milik PT. Transportasi Jakarta yang disebut Bus Royaltrans.

Sebagai pendatang baru, PT. Transportasi Jakarta mengembangkan inovasi layanan transportasi publik yakni Layanan Bus Premium Royaltrans. Bila dibandingkan dengan kompetitornya yang membedakan Royaltrans adalah Bus Premium yang didesain dengan nuansa yang classic yang dilengkapi dengan kursi duduk sofa yang nyaman, adanya USB charge, wifi, dan tempat minum serta pelayanan pengemudi yang telah tersertifikasi. Bus yang digunakan adalah bus Mercedez Benz of $917 \mathrm{OH}$ dengan desain karoseri dari Tentrem dan New Armada, bus Royaltrans dapat menampug 30 penumpang dalam 1 kali perjalanan. Bus Royaltrans diawal launching melayani rute Sumarecon Bekasi - Blok M, Sumarecon Bekasi - Kuningan, Bekasi Timur - Tebet, dan Bekasi Timur - Kalideres. Yang mendorong peneliti mengamati ke Bus Royaltrans yakni, harga bus Royaltrans jauh lebih mahal dibandingkan dengan beberapa kompetitor lainnya, dengan harga yang ditawarkan sebesar Rp. 20.000/single trip dibandingkan dengan kompetitor lainnya yang rata - rata Rp. 15.000/single trip namun bila diamati sebagai pendatang baru, Bus
Royaltrans mampu menunjukkan peningkatan jumlah pelanggan yang cukup signifikan hingga adanya komnitas untuk pelanggan Royaltrans untuk mengetahui jadwal dan infromasi - informasi tentang layanan Bus Premium Royaltrans. Hal ini membuat adanya minat pelanggan dan keinginan pelanggan untuk terus menggunakan layanan tersebut secara kontinue. Peningkatan jumlah pelanggan ini tak luput dari bagaimana pihak manajemen melakukan strategi pemasaran dan sosialisasi kepada pelanggan di area kota Bekasi, bila diamati berdasarkan data dari penjualan PT Transportasi Jakarta menunjukkan bahwa:

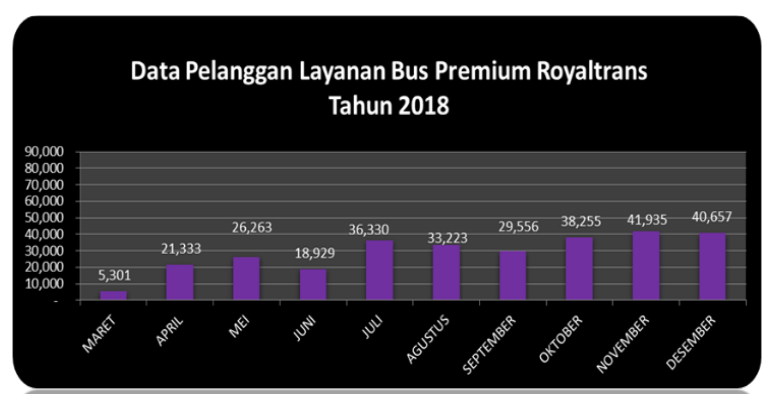

Gambar 1. Data Penjualan Layanan Bus Royaltrans Tahun 2018

Sumber: Data Diolah dari Data Penjualan PT

Transpportasi Jakarta (2018)

Gambar 1, menunjukkan bahwa data penjualan layanan bus premium Royaltrans bila dikalkulasikan rata - rata dalam satu tahun menunjukkan 29.178 Pelanggan yang menggunakan layanan bus Premium Royaltrans dalam kurung waktu 10 Bulan beroperasinya Bus Royaltrans. Hal ini menunjukkan adanya peningkatan yang cukup signifikan bagi Royaltrans yang kehadirannya langsung diterima oleh masyarakat sekitar, peneliti melakukan serangkaian observasi dan wawancara terhadap 10 konsumen pengguna Layanan Bus Premium Royaltrans untuk memperdalam fenomena dan hasilnya sekitar $80 \%$ konsumen tersebut adalah pelaku Repurchase Intention yang rata - rata konsumen melakukan Repurchase Intention 
karena jangkauan integrasi yang ditawarkan sangat memudahkan konsumen untuk menuju ke kantor serta keamanan dan kenyamanannya menjadi poin plus konsumen memutuskan untuk melakukan pembelian ulang layanan tersebut. Dalam observasi yang dilakukan oleh peneliti selama menggunakan Layanan Bus Premium Royaltrans yakni adanya perbedaan pelayanan yang ditawarkan oleh Layanan Bus Premium Royaltrans terlihat sangat jelas dari lokasi penaikan dan penurunan, suasana di dalam bus, harga yang ditawarkan berbeda dengan bus Transjakarta pada umumnya, serta karakteristik konsumen yang menggunakan Layanan Bus Premium Royaltrans. Dari hasil observasi dan wawancara yang dilakukan di lokasi, peneliti merangkup beberapa variabel yang mempengaruhi Repurchase Intention dan akhirnya menemukan 3 variabel yang paling mendekati dengan Repurchase Intention dengan yakni Experiential Marketing, variabel ini dipilih dikarenakan para konsumen merasakan produk jasa yang digunakan dengan panca inderanya dan lebih menekankan kesan kesannya secara emosional, lalu variabel Self Efficacy dan Trust variabel ini dipilih atas hasil observasi dan wawancara yang terlihat bahwa konsumen me - efikasi dirinya dan komitmen dengan layanan jasa transportasi yang digunakan serta adanya kepuasaan yang konsumen rasakan, namun pemilihan tiga variabel tersebut belum begitu kuat untuk fenomena ini. Maka dengan ini untuk memperkuat fenomena tersebut, penulis juga melakukan pra-survei dengan memberikan pernyataan yang berkaitan dengan arah variabel yang disebarkan kepada 30 responden yang pernah melakukan perjalanan menggunakan Layanan Bus Premium Royaltrans.

Berdasarkan hasil pra survei terlihat para responden mendominasi mengarah pada variabel Experiential Marketing dan Trust yang mempengaruhi untuk melakukan pemakaian jasa ulang dan akan merekomendasikan Layanan Bus Premium Royaltrans kepada orang lain. Hal lain juga dapat terlihat dari pernyataan yang mewakili variabel Self Efficacy bahwa responden dapat menilai kemampuan dirinya untuk mampu menggunakan layanan kelas premium, merekomendasikan dan berkomitmen untuk tetap menggunakan layanan bus premium Royaltrans sebagai sarana transportasi publik yang dibutuhkan ketika berangkat kerja dan bertemu dengan rekan bisnis. Dari hasil datadata yag telah terkumpul diatas, maka peneliti tertarik untuk menjadikan Layanan Bus Premium Royaltrans PT Transportasi Jakarta sebagai objek penelitiannya karena apabila dilihat dari jumlah konsumen Transjakarta menjadi marketshare pada transportasi publik yang memperoleh per harinya mencapai 800.000 pelanggan perhari dalam melayani bus BRT (Bus Rafid Transit), Bus Non BRT (Non Bus Rafid Transit), Bus Feeder rumah susun, Jakarta Explorer, Tanah Abang Explorer, Bus Wisata dan Transcare, serta Transjakarta mendapatkan prestasi dalam kategori The Best in Ground Transportation Industry dan The Best Strategy Into Performance Execution Officer pada kompetisi bergengsi bertajuk Strategy Into Performace Execution Excellence (SPEx2) Award 2018. Hal ini sudah cukup baik dan menjadi alasan peneliti ingin meneliti apakah ada kaitannya dari data-data tersebut terhadap Repurchase Intention dari para pelanggan pengguna Layanan Bus Premium Royaltrans. Hal ini sangat berguna untuk PT Transportasi Jakarta dalam meningkatkan target jumlah pelanggan dan meningkatkan nilai key performance dan financial indicator di laporan keuangan. Banyak cara yang dapat dilakukan perusahaan untuk dapat bersaing di dalam ruang lingkup transportasi publik, salah satunya dengan meilihat dari perilaku konsumen. Perilaku konsumen merupakan tindakan yang langsung terlibat dalam mendapatkan, mengkonsumsi dan 
menghabiskan produk dan jasa termasuk proses keputusan yang mendahului dan menyusuli tindakan ini (Fadhila dan Ridho 2013). Istilah perilaku erat hubungannya dengan objek yang studinya diarahkan pada permasalahan manusia dibidang pemasaran, konsep perilaku konsumen secara terus menerus dikembangkan dengan berbagai pendekatan. Memahami perilaku konsumen dan pelanggan tidak sederhana, pelanggan mungkin saja menyatakan kebutuhan dan keinginan mereka. Tetapi mereka malah bertindak yang lebih dalam dan biasa saja mereka menanggapi pengaruh yang mengubah pola pikir mereka pada menitmenit akhir. Perilaku konsumen sangat dipengaruhi oleh keadaan dan situasi lapisan masyarakat dimana ia dilahirkan dan berkembang. Ini berarti konsumen berasal dari lapisan masyarakat atau lingkungan yang berbeda akan mempunyai penilaian, kebutuhan, pendapat, sikap, dan selera yang berbeda-beda, sehingga pengambilan keputusan dalam tahap pembelian ulang akan dipengaruhi oleh beberapa faktor. Faktor yang mempengaruhi perilaku konsumen menurut Kotler (2008) antara lain faktor kebudayaan, faktor sosial, faktor pribadi dan faktor psikologis. Selain memahami perilaku konsumen, perusahaan juga harus memahami faktor-faktor yang mempengaruhi pembelian ulang para pelanggan. Setelah memahami perilaku konsumen dan faktor-faktor yang mempengaruhi pembelian ulang, perusahaan juga harus melakukan suatu strategi agar produk yang ditawarkan dapat dikenal oleh masyarakat, salah satunya dengan cara menghubungkan pelanggan dengan suatu brand itu sendiri atau lebih dikenal dengan Pengalaman Marketing.

Menurut Schmitt (2011) Experiential Marketing adalah tentang menghubungkan pelanggan dengan brand itu sendiri. Experiential Marketing merupakan proses penawaran produk dan jasa oleh pemasar kepada konsumen dengan perangsangan emosi konsumen yang dihasilkan berbagai pengalaman bagi konsumen, dapat dicontohkan setiap harinya pelanggan banyak yang menikmati layanan bus Premium Royaltrans untuk melakukan perjalanan ke kantor demi menikmati kenyamanan dan ketenangan selama perjalanan. Pihak pemasar harus mengembangkan inovasi Bus Royaltrans selain menarik pendatang baru untuk berlangganan dengan layanan tersebut, maka dituntut pula harus membuat strategi pemasaran untuk bisa mempertahankan pelanggan lamanya. Sehingga tingkat Repurchase Intention pelanggannya mencapai target yang signifikan dan sebaik mungkin. Minat konsumen untuk melakukan Repurchase Intention untuk layanan transportasi Bus Premium dikhawatirkan akan kalah bersaing dengan layanan transportasi bus premium lainnya. Faktor-faktor yang dianggap mampu memperngaruhi Repurchase Intention diantaranya adalah Experiental Marketing, setiap pelanggan ingin mendapatkan sensasi pengalaman yang menyenangkan saat berkunjung pada moda transportasi publik, dengan memberikan pengalaman marketing akan membuat pelanggan memiliki kemampuan untuk membedakan produk dan jasa karena dengan melalui lima pendekatan (Sense, Feel, Think, Act, Relate) pelanggan dapat merasakan dan memperoleh pengalaman secara langsung baik sebelum maupun saat pelanggan mengkonsumsi sebuah produk atau jasa. Experiental Marketing dari suatu bus akan sangat diperhatikan dan dirasakan oleh pelanggan sebagai refrensi untuk datang kembali menggunakan layanan bus premium selanjutnya.

Pamudi, P., \& Suryani, E. (2018) menyatakan bahwa Transportasi adalah berpindahnya sesuatu dari satu tempat ketempat lain dengan menggunakan alat, pemindahan tersebut bisa menggunakan alat atau tenaga lain. Menurut Morlok (2018) transportasi didefinisikan sebagai suatu 
kegiatan memindahkan atau mengangkut sesuatu dari satu tempat ketempat lain, sedangkan menurut Bowersox (2018) transportasi adalah suatu perpindahan barang atau penumpang dari suatu tempat ketempat lain, dimana barang atau penumpang dipindahkan ke tempat tujuan dibutuhkan. Pengertian transportasi adalah kegiatan memindahkan sesuatu (barang dan/atau manusia).

Moda transportasi menurut Djoko Setijowarno dan Frazila (2001), memiliki ciriciri yang berlainan, yakni dalam hal: (a) Kecepatan, menunjukan berapa lama waktu yang dibutuhkan untuk bergerak antara dua lokasi; (b) Tersedianya pelayanan (availability of service), menyangkut kemampuan untuk menyelenggarakan hubungan antara dua lokasi; (c) Pengoperasiaan yang diandalkan (dependability of operation), menunjukan perbedaan-perbedaan yang terjadi antara kenyataan dan jadwal yang ditentukan; (d) Kemampuan (capability), merupakan kemampuan untuk dapat menangani segala bentuk dan keperluan akan pengangkutan; (e) Frekuensi adalah banyaknya gerakan atau hubungan yang dijadwalkan.

Menurut Keputusan Menteri Perhubungan No. KM.35 tahun 2003 tentang Penyelenggaraan Angkutan Orang di Jalan dengan kendaraan umum: angkutan adalah angkutan dari pemindahan orang dan barang dari satu tempat ke tempat lain dengan menggunakan kendaraan. Menurut Nasution (2008) peranan pengangkutan mencakup bidang yang luas di dalam kehidupan manusia yang meliputi atas berbagai aspek, seperti aspek sosial dan budaya, aspek politis dan pertahanan, aspek hukum, aspek teknik, dan aspek ekonomi.

Menurut Engel at al dalam buku Etta Mamang Sangadji (2013) perilaku konsumen adalah tindakan yang langsung terlibat dalam Pemerolehan, Pengeonsumsian, dan penghasilan produk/jasa, termasuk proses yang mendahului dan menyusul tindakan ini.

Perilaku konsumen adalah tindakan yang langsung terlibat dalam mendapatkan, mengkonsumsi, dan menghabiskan produk dan jasa, termasuk proses keputusan yang proses keputusan yang mendahului dan mengikuti tindakan ini mendahului dan menyusuli tindakan ini (Fadila dan Ridho, 2013). Menurut Mowen dan Minor dalam buku Etta Mamang Sangadji (2013) perilaku konsumen adalah studi unit-unit dan proses pembuatan keputusan yang terlibat dalam penerimaan, penggunaan dan pembelian, dan penentuan barang, jasa dan ide. Menurut Schiffman dan Kanuk dalam Sumarwan dkk (2012) mendefinisikan perilaku konsumen sebagai tindakan yang langsung terlibat dalam mendapatkan, mengonsumsi dan menghabiskan produk atau jasa, termasuk keputusan yang mendahului dan mengikuti tindakan ini.

Dinamika kecemasan menghadapi suatu perilaku yang ditinjau dari kognitif terjadi karena adanya persepsi negatif kemampuan yang dimilikinya seperti merasa tidak punya persiapan diri, merasa tidak mampu menghadapi hambatan, tidak mampu mengontrol respon fisik, hal tersebut menyebabkan kecemasan seseorang untuk melakukan suatu pekerjaan. Self Efficacy adalah penilaian diri, apakah dapat melakukan tindakan yang baik atau buruk, tepat atau salah, bisa atau tidak bisa mengerjakan sesuai dengan yang dipersyaratkan. Self Efficacy berbeda dengan aspirasi (cita-cita), karena cita-cita menggambarkan sesuatu yang ideal yang seharusnya dapat dicapai, sedang efikasi menggambarkan penilaian kemampuan diri (Alwisol, 2009). Konsep ini mengacu pada pertimbangan seberapa besar keyakinan seseorang tentang kemampuannya melakukan sejumlah aktivitas dan kemampuannya menyelesaikan tugas-tugas. Sementara, dikutip dari Baron dan Byrne (2003). Niu 
(2010) menyebut self efficacy adalah hasil interaksi antara lingkungan eksternal, mekanisme penyesuaian diri serta kemampuan personal, pengalaman dan pendidikan. Self efficacy memiliki beberapa yang mempunyai implikasi penting pada kinerja, artinya self-efficacy bersifat spesifik karakteristik dalam tugas dan situasi yang dihadapi.

Menurut Ding Mao (Hendia, 2013), Trust adalah Keyakinan bahwa kata atau janji seseorang dapat dipercaya dan seseorang akan memenuhi kewajibannya dalam sebuah hubungan pertukaran. Membangun kepercayaan dalam hubungan jangka panjang dengan pelanggan adalah suatu faktor yang penting untuk menciptakan loyalitas pelanggan. Kepercayaan ini tidak begitu saja dapat diakui oleh pihak lain atau mitra bisnis, melainkan harus dibangun mulai dari awal dan dapat dibuktikan. Moorman, Zaltman dan Deshpande (dalam Rosidah, 2011) mengatakan "trust generally is viewed as an essential ingredient for successful relationships". Morgan dan Hunt (dalam Rosidah, 2011) mengkonseptualisasikan "trust as existing when one party has confidence in a exchange partners reliability and integrity". Dimana kepercayaan muncul ketika adanya keyakinan dari pihak konsumen yaitu pelanggan pada reliabilitas dan integritas dari rekan pertukaran.

Menurut Siagian dan Cahyono (2014) kepercayaan merupakan sebuah keyakinan dari salah satu pihak mengenai maksud dan perilaku yang ditujukan kepada pihak yang lainnya, dengan demikian kepercayaan konsumen didefinisikan sebagai suatu harapan konsumen bahwa penyedia jasa bisa dipercaya atau diandalkan dalam memenuhi janjinya.

Repurchase Intention adalah perilaku konsumen yang menunjukan sejauh mana komitmennya dalam melakukan pembelian. Sedangkan menurut Kotler, Bowen dan Makens (2014), Repurchase Intention timbul setelah adanya proses evaluasi alternatif. Dalam proses evaluasi, seseorang akan membuat suatu rangkaian pilihan mengenai produk yang hendak dibeli atas dasar merek maupun minat. Menurut Sukmawati dan Suyono dalam Pramono dikutip dari Annafik dan Rahardjo (2012), minat beli merupakan bagian dari komponen perilaku dalam sikap mengkonsumsi. Minat beli konsumen adalah tahap dimana konsumen membentuk pilihan mereka diantara beberapa merek yang tergabung dalam perangkat pilihan. Kemudian pada akhirnya melakukan suatu pembelian pada suatu altenatif yang paling disukainya atau proses yang dilalui konsumen untuk membeli suatu barang atau jasa yang didasari oleh bermacam pertimbangan. Minat beli adalah perilaku konsumen yang menunjukan sejauh mana komitmennya dalam melakukan pembelian. Sedangkan menurut Kotler, Bowen dan Makens (2014), minat beli timbul setelah adanya proses evaluasi alternatif. Dalam proses evaluasi, seseorang akan membuat suatu rangkaian pilihan mengenai produk yang hendak dibeli atas dasar merek maupun minat. Menurut Hawkins et al (2007) pembelian kembali sebagai suatu kegiatan membeli kembali yang dilakukan oleh konsumen terhadap suatu produk dengan merek yang sama tanpa diikuti oleh perasaan yang berarti terhadap produk tersebut. Terdapat dua kemungkinan yang dapat menyebabkan seseorang melakukan pembelian kembali suatu produk. Pertama, konsumen merasa puas dengan pembelian yang mereka lakukan. Kedua, pelanggan merasa tidak puas tetapi mereka tetap melakukan pembelian kembali, Untuk kemungkinan kedua ini biasanya disebabkan mereka menganggap biaya yang harus mereka keluarkan untuk mencari, mengevaluasi, dan mengadopsi produk dengan merek lain (switching cost) terlalu tinggi.

Menurut Schmitt (2011) Experiential Marketing adalah tentang menghubungkan pelanggan dengan brand itu sendiri. 
Experiential Marketing merupakan suatu proses penawaran produk dan jasa oleh pemasar kepada konsumen dengan perangsangan emosi konsumen yang menghasilkan berbagai pengalaman bagi konsumen. Pemasaran berbasis pengalaman (Experiential Marketing) merupakan sebuah pendekatan untuk memberikan informasi yang lebih dari sekedar informasi mengenai sebuah produk atau jasa. Sedangkan menurut Wijaya, A. (2018), Experiential Marketing memiliki hubungan yang signifikan terhadap Repurchase Intention. Dan Menurut Tetanoe, V. R. (2014), Experiential Marketing memiliki pengaruh yang signifikan terhadap Pembelian Ulang. Dengan demikan berdasarkan kajian teori dan kajian penelitian terdahulu, maka hipotesis pertama pada penelitian ini yaitu.

H1 : Faktor Experiental Marketing berpengaruh positif signifikan terhadap Repurchase Intention.

Menurut (Alwisol, 2009), Self Efficacy adalah penilaian diri, apakah dapat melakukan tindakan yang baik atau buruk, tepat atau salah, bisa atau tidak bisa mengerjakan sesuai dengan yang dipersyaratkan. Self Efficacy berbeda dengan aspirasi (cita-cita), karena cita-cita menggambarkan sesuatu yang ideal yang seharusnya dapat dicapai, sedang efikasi menggambarkan penilaian kemampuan diri. Menurut Bandura (1997), terdapat beberapa elemen dalam Self efficacy yang dapat mempengaruhi minat beli ulang oleh konsumen. Dimana magnitude atau level, generality dan strength dapat mempengaruhi keputusan konsumen untuk melakukan pembelian ulang. Dan menurut Wulandari, S (2013), Self Efficacy mempunyai kontribusi terhadap minat berwirausaha pada siswa kelas XII di SMK Negeri 1 Surabaya. Bila menarik teori dari penelitian terdahulu, maka dengan adanya Self Efficacy dapat mempengaruhi minat beli ulang. Berdasarkan uraian tersebut dapat disimpulkan hipotesisnya yaitu: $\mathrm{H} 2$ :
Faktor Self Efficacy berpengaruh positif dan signifikan terhadap Repurchase Intention.

Menurut Ding Mao (Hendia, 2013), Trust adalah Keyakinan bahwa kata atau janji seseorang dapat dipercaya dan seseorang akan memenuhi kewajibannya dalam sebuah hubungan pertukaran, sedangkan menurut Siagian dan Cahyono (2014) kepercayaan merupakan sebuah keyakinan dari salah satu pihak mengenai maksud dan perilaku yang ditujukan kepada pihak yang lainnya. Dan menurut Sari, I. D. P., Nobelson, N., \& Sembiring, R. (2018), Trust menunjukan tingkat signifikan bahwa variabel kepercayaan (trust) berada pada t-hitung sebesar 4,809 nilai tersebut lebih besar dari pada nilai signifikansi. Maka dengan ini, membangun kepercayaan dalam hubungan jangka panjang dengan pelanggan adalah faktor yang penting untuk menciptakan loyalitas pelanggan dan dapat disimpulkan bahwa Trust berpengaruh terhadap Repurchase Intention. Berdasarkan uraian tersebut dapat disimpulkan hipotesisnya yaitu: H3 : Faktor Trust berpengaruh signifikan terhadap Repurchase Intention.

\section{METODE}

Proses penelitian ini diawali dengan kegiatan mengidentifikasi permasalahan ditempat yang akan digunakan sebagai lokasi penelitian, perumusan masalah yang teridentifikasi, pengumpulan dasar teori yang memperkuat landasan dalam variabel dan penyusunan metode dalam pengumpulan data, waktu penelitian dimulai sejak Februari sampai dengan Juni 2019. Penelitian ini menganalisa bagaimana pengaruh Experiential Marketing, Self Efficacy dan Trust terhadap Repurchase Intention. Tempat dan objek penelitian dilakukan pada Pelanggan Bus Royaltrans di Wilayah Kota Bekasi. Data hasil kuesioner yang didapatkan menjadi bahan penelitian yang dimaksudkan untuk mengetahui apakah Experiential Marketing, Self Efficacy dan Trust memiliki 
pengaruh terhadap Repurchase Intention Layanan Bus Premium Royaltrans.

Skala pengukuran yang digunakan dalam penelitian ini adalah Skala Likert. Skala Likert adalah metode yang digunakan untuk mengukur sikap, pendapat, dan persepsi seseorang atau sekelompok orang tentang fenomena sosial (Sugiyono, 2013). Dengan Skala Likert, maka variable yang akan diukur dijabarkan menjadi indikator variabel. Kemudian indikator tersebut dijadikan sebagai titik tolak untuk menyusun item-item instrument yang dapar berupa pernyataan atau pertanyaan. Skala Likert menggunakan lima tingkat jawaban, Sangat Setuju (SS), setuju $(\mathrm{S})$, netral $(\mathrm{N})$, tidak setuju (TS), sangat tidak setuju (STS)

Menurut Sugiyono (2013) populasi adalah wilayah generalisasi yang terdiri atas objek atau subjek yang mempunyai kualitas dan karakteristik tertentu yang ditetapkan oleh peneliti untuk dipelajari dan kemudian ditarik kesimpulannya. Jadi populasi bukan hanya orang, tetapi juga objek dan benda benda alam lain. Maka dalam penelitian ini, populasi yang akan digunakan adalah Pelanggan Bus Royaltrans di wilayah Kota Bekasi yang menggunakan layanan bus premium Royaltrans lebih dari 3 kali. Dimana jumlah populasi tidak diketahui.

Menurut Sugiyono (2013) sampel adalah bagian dari jumlah dan karakteristik yang dimiliki oleh populasi tersebut. Bila populasi besar dan peneliti tidak dapat mungkin mempelajari semua yang ada pada populasi, misalnya karena keterbatasan dana, tenaga dan waktu, maka peneliti dapat menggunakan sampel dari populasi itu. Sampel yang diambil dari populasi tersebut harus betulbetul representatif (mewakili). Berdasarkan uraian tersebut, metode pengambilan sampel yang digunakan peneliti adalah purposive sampling. Menurut Sugiyono (2013) purposive sampling adalah teknik pengambilan sampel sumber data dengan pertimbangan tertentu. Pertimbangan tertentu ini, misalnya orang tersebut yang dianggap paling mengetahui tentang apa yang kita harapkan, atau mungkin dia sebagai penguasa sehingga akan memudahkan peneliti menjelajahi objek/situasi sosial yang diteliti. Alasan menggunakan purposive sampling karena peneliti mengharapkan sampel tersebut sesuai dengan persyaratan atau tujuan peneliti sehingga memperoleh data yang akurat.

Menurut Hair et al (2010) merekomendasikan jumlah sampel minimal adalah 5 kali dari jumlah item indikator yang terdapat di kuesioner. Bila terdapat 20 indikator, besarnya sampel adalah antara 100200 maka jumlah sampel yang akan diambil sebanyak 100-200 responden sebagai syarat untuk goodness-of-fit yang baik. Jumlah sampel yang digunakan pada penelitian ini adalah :

Jumlah Sampel $=$ Indikator $\times 5=32 \times 5$ $=160$ Sampel. Teknik pengambilan sampel ini digunakan untuk melakukan penyebaran kuesioner langsung kepada responden.

\section{HASIL DAN PEMBAHASAN}

\begin{tabular}{|c|c|c|c|}
\hline Variabel & Indikator & $\begin{array}{c}\text { Outer } \\
\text { Loading }\end{array}$ & Keterangan \\
\hline Experiental & EM1 & 0.8 & Valid \\
\hline \multirow[t]{9}{*}{ Marketing } & EM2 & 0.799 & Valid \\
\hline & EM3 & 0.857 & Valid \\
\hline & EM4 & 0.795 & Valid \\
\hline & EM5 & 0.865 & Valid \\
\hline & EM6 & 0.691 & Valid \\
\hline & EM7 & 0.681 & Valid \\
\hline & EM8 & 0.835 & Valid \\
\hline & EM9 & 0.835 & Valid \\
\hline & EM10 & 0.784 & Valid \\
\hline \multirow[t]{6}{*}{ Self Efficacy } & SE1 & 0.84 & Valid \\
\hline & SE2 & 0.864 & Valid \\
\hline & SE3 & 0.792 & Valid \\
\hline & SE4 & 0.849 & Valid \\
\hline & SE5 & 0.784 & Valid \\
\hline & SE6 & 0.842 & Valid \\
\hline \multirow[t]{10}{*}{ Trust } & TR1 & 0.674 & Valid \\
\hline & TR2 & 0.826 & Valid \\
\hline & $T R 3$ & 0.866 & Valid \\
\hline & TR4 & 0.848 & Valid \\
\hline & TR5 & 0.668 & Valid \\
\hline & TR6 & 0.781 & Valid \\
\hline & TR7 & 0.804 & Valid \\
\hline & TR8 & 0.832 & Valid \\
\hline & TR9 & 0.778 & Valid \\
\hline & TR10 & 0.728 & Valid \\
\hline \multirow{4}{*}{$\begin{array}{c}\text { Repurchase } \\
\text { Intention }\end{array}$} & $R / 1$ & 0.717 & Valid \\
\hline & $R / 2$ & 0.764 & Valid \\
\hline & $R / 3$ & 0.83 & Valid \\
\hline & $R / 4$ & 0.754 & Valid \\
\hline
\end{tabular}


Jurnal Ilmiah Manajemen dan Bisnis

ISSN 1693-7619 (Print) I ISSN 2580-4170 (Online)

\begin{tabular}{|c|c|c|c|}
\hline Variabel & Indikator & $\begin{array}{c}\text { Outer } \\
\text { Loading }\end{array}$ & Keterangan \\
\hline & $R / 5$ & 0.832 & Valid \\
\hline & $R / 6$ & 0.852 & Valid \\
\hline
\end{tabular}

ambar 2. Hasil Pengujian Convergent Validity

Berdasarkan Tabel 1 dan Gambar 1 terlihat bahwa model struktual yang merupakan hasil data yang diolah menggunakan Smart PLS 3.0 jika dilihat dalam model struktual tersebut dimana nilai outer model atau korelasi antar konstruk dengan variabel sebagian sudah memenuhi convergent validity, dimana semua indikator memiliki nilai loading factor lebih atau tidak kurang dari 0,50. Pada Tabel 1 dan Gambar 1 semua indikator telah mempengaruhi convergent validity karena memiliki nilai factor loading di atas 0,50 .

Tabel 2 . Discriminant Validity

\begin{tabular}{lcccc}
\hline Indikator & $\begin{array}{c}\text { Experiential } \\
\text { Marketing }\end{array}$ & Self Efficacy & Trust & $\begin{array}{c}\text { Repurchase } \\
\text { Intention }\end{array}$ \\
\hline EM1 & 0.8 & 0.626 & 0.613 & 0.605 \\
EM2 & 0.799 & 0.675 & 0.626 & 0.629 \\
EM3 & 0.857 & 0.643 & 0.628 & 0.66 \\
EM4 & 0.795 & 0.584 & 0.669 & 0.609 \\
EM5 & 0.865 & 0.7 & 0.709 & 0.696 \\
EM6 & 0.691 & 0.597 & 0.67 & 0.598 \\
EM7 & 0.681 & 0.552 & 0.605 & 0.582 \\
EM8 & 0.835 & 0.7 & 0.632 & 0.638 \\
EM9 & 0.835 & 0.755 & 0.713 & 0.717 \\
EM10 & 0.784 & 0.673 & 0.682 & 0.638 \\
\hline SE1 & 0.69 & 0.84 & 0.713 & 0.687 \\
SE2 & 0.699 & 0.864 & 0.744 & 0.723 \\
SE3 & 0.667 & 0.792 & 0.727 & 0.687 \\
SE4 & 0.667 & 0.849 & 0.75 & 0.713 \\
SE5 & 0.686 & 0.784 & 0.694 & 0.683 \\
SE6 & 0.672 & 0.842 & 0.716 & 0.747 \\
\hline
\end{tabular}

\begin{tabular}{lcccc}
\hline Indikator & $\begin{array}{c}\text { Experiential } \\
\text { Marketing }\end{array}$ & Self Efficacy & Trust & $\begin{array}{c}\text { Repurchase } \\
\text { Intention }\end{array}$ \\
\hline TR2 & 0.651 & 0.719 & 0.826 & 0.674 \\
TR3 & 0.692 & 0.743 & 0.866 & 0.697 \\
TR4 & 0.663 & 0.691 & 0.848 & 0.645 \\
TR5 & 0.497 & 0.549 & 0.668 & 0.565 \\
TR6 & 0.636 & 0.678 & 0.781 & 0.67 \\
TR7 & 0.703 & 0.733 & 0.804 & 0.747 \\
TR8 & 0.73 & 0.793 & 0.832 & 0.789 \\
TR9 & 0.661 & 0.683 & 0.778 & 0.694 \\
TR10 & 0.624 & 0.618 & 0.728 & 0.613 \\
\hline RI1 & 0.523 & 0.555 & 0.52 & 0.717 \\
RI2 & 0.525 & 0.64 & 0.608 & 0.764 \\
RI3 & 0.661 & 0.672 & 0.685 & 0.83 \\
RI4 & 0.59 & 0.603 & 0.635 & 0.754 \\
RI5 & 0.752 & 0.78 & 0.807 & 0.832 \\
RI6 & 0.722 & 0.767 & 0.76 & 0.852 \\
\hline
\end{tabular}

Tabel 2 terlihat bahwa korelasi konstruk EM (Experiential Marketing) beserta indikatornya lebih tinggi dibandingkan korelasi dengan indikator konstruk lainya SE (Self Efficacy), TR (Trust), dan RI (Repurchase Intention). Kemudian korelasi konstruk SE (Self Efficacy), beserta indikatornya lebih tinggi dibandingkan korelasi dengan indikator konstruk lainnya EM (Experiential Marketing), TR (Trust), dan RI (Repurchase Intention).. Selanjutnya korelasi konstruk TR (Trust) beserta indikatornya lebih tinggi dibandingkan korelasi dengan indikator konstruk lainnya EM (Experiential Marketing), SE (Self Efficacy) dan RI (Repurchase Intention) serta korelasi konstruk RI (Repurchase Intention) beserta indikatormya lebih tinggi dibandingkan korelasi dengan indikator konstruk lainya EM (Experiential Marketing), (SE (Self Efficacy) dan TR (Trust).

Metode lain untuk melihat discriminant validity adalah dengan membandingkan nilai square root of average variance extracted (AVE) setiap konstruk dengan korelasi antara konstruk lainnya dalam model, maka dikatakan memiliki nilai discriminant validity yang baik.

Uji lainnya untuk melihat discriminant validity adalah dengan melihat (Average Variance Extracted) AVE, yang dipersyaratkan model yang baik jika AVE masing - masing konstruk nilainya lebih besar dari 0,50. Pada penelitian kali ini, hasil pengujian discriminant validity (AVE) yakni: 
Tabel 3. Hasil Uji Discriminant Validity Average Variance Extracted (AVE)

\begin{tabular}{lc}
\hline \multicolumn{1}{c}{ Variabel } & $\begin{array}{c}\text { Average Variance } \\
\text { Extracted (AVE) }\end{array}$ \\
\hline Experiential Marketing & 0.634 \\
Repurchase Intention & 0.629 \\
Self Efficacy & 0.688 \\
Trust & 0.614 \\
\hline
\end{tabular}

Tabel 3, diketahui bahwa variabel Experiential Marketing memiliki hasil sebesar 0.634, kemudian Self Efficacy memiliki hasil 0.688, selanjutnya Trust memiliki hasil sebesar 0,614, dan Repurchase Intention memiliki hasil 0.629. Dari hasil keseluruhan dapat kita lihat bahwa Self Efficacy memiliki hasil yang paling tinggi berarti variabel Self Efficacy memiliki tingkat signifikan yang paling besar, namun jika dilihat secara keseluruhan variabel pada penelitian ini sudah signifikan.

Tabel 4. Composite Reliability dan Cronbach Alpha

\begin{tabular}{lcccc}
\hline \multicolumn{1}{c}{ Variabel } & $\begin{array}{c}\text { Compos } \\
\text { ite } \\
\text { Reliabilit } \\
\boldsymbol{y}\end{array}$ & $\begin{array}{c}\text { Keterang } \\
\text { an }\end{array}$ & $\begin{array}{c}\text { Cronbac } \\
\text { hs Alpha }\end{array}$ & $\begin{array}{c}\text { Keterang } \\
\text { an }\end{array}$ \\
$\begin{array}{l}\text { Experiential } \\
\text { Marketing }\end{array}$ & 0.945 & Reliabel & 0.935 & Reliabel \\
$\begin{array}{l}\text { Self Efficacy } \\
\text { Trust }\end{array}$ & 0.93 & Reliabel & 0.909 & Reliabel \\
$\begin{array}{l}\text { Repurchase } \\
\text { Intention }\end{array}$ & 0.94 & Reliabel & 0.929 & Reliabel \\
\hline
\end{tabular}

Tabel 4 menunjukan bahwa pengujian composite reliability dan cronbachs alpha menunjukkan nilai yang memuaskan dimana composite reliability dan cronbachs alpha memiliki reliabilitas $\geq 0,70$ yang memiliki arti bahwa konstruk memiliki reliabilitas yang baik atau kuesioner yang digunakan sebagai alat dalam penelitian ini telah andal atau konsisten. Menurut Guilford dalam Iskandar (2009:33) menggunakan derajat reliabilitas adalah sebagai berikut:

Tabel 5. Derajat Reliabilitas

\begin{tabular}{cc}
\hline Koefisien Korelasi & Kriteria Reliabilitas \\
\hline $0,81<r<1,00$ & Sangat Tinggi \\
$0,61<r<0,80$ & Tinggi \\
$0,41<r<0,60$ & Cukup \\
$0,21<r<0,40$ & Rendah
\end{tabular}

Berdasarkan Tabel 5 derajat reliabilitas, maka nilai Composite Reliability variabel Experiental Markeing, Self Efficacy, Trust dan Repurchase Intention mempunyai nilai yaitu 0,91- 0,94. Berdasarkan derajat reliabilitas maka nilai Composite Reliability dapat dikatakan reliabel sebab nilai tersebut berada pada derajat reliabilitas yang sangat tinggi. Begitu pula dengan nilai Cronbachs Alpha pada Experiental Markeing, Self Efficacy, Trust dan Repurchase Intention mempunyai nilai yaitu 0,88 - 0,93. Berdasarkan derajat reliabilitas maka nilai Cronbachs Alpha dapat dikatakan reliabel sebab nilai tersebut berada diatas $>0,70$, maka pada derajat reliabilitas yang tinggi.

Setelah model yang diestimasi memenuhi kriteria Outer Model, berikutnya dilakukan pengujian model structural (Inner model). Pengujian inner model adalah pengembangan model berbasis konsep dan teori dalam rangka menganalisis hubungan antara variabel eksogen dan endogen telah dijabarkan dalam rerangka konseptual. Tahapan pengujian terhadap model struktural (Inner model) dilakukan dengan langkahlangkah berikut ini:

Nilai R-square yang merupakan uji goodness-fit model Repurchase Intention Sebesar 0.788. Model pengaruh variabel laten independen (Experiental Marketing), (Self Efficacy) dan (Trust) terhadap variabel dependen (Repurchase Intention) memberikan nilai R-square sebesar 0.788 yang dapat diinterpretasikan bahwa variabel konstruk Experiental Marketing, Self Efficacy dan Trust sebesar 78,8\% sedangkan 21,2\% dijelaskan oleh variabel lain diluar yang akan diteliti.

Nilai predictive relevance untuk variabel Repurchase Intention di peroleh dengan rumus:

$$
\begin{aligned}
& Q^{2}=1-\left(1-\left(R^{2}\right)^{2}\right) \\
& Q^{2}=1-\left(1-(0,788)^{2}\right)
\end{aligned}
$$




$$
\begin{aligned}
& Q^{2}=1-(1-0,621) \\
& Q^{2}=1-0,379=0,621
\end{aligned}
$$

Hasil perhitungan diatas menunjukkan bahwa nilai predictive relevance pada variabel Repurchase Intention (Dependent Variable) sebesar 0,621 ( $>0)$. Hal ini berarti bahwa $62,1 \%$ variasi pada variabel Repurchase Intention dijelaskan oleh variabel-variabel yang digunakan. Dengan demikian model dikatakan layak untuk memiliki nilai prediktif yang relevan.

Goodness of Fit (GoF) menggambarkan tingkat kesesuaian model secara keseluruhan yang dihitung dari residual kuadrat dari model yang diprediksi dibandingkan dengan data yang sebenarnya yang diperkenalkan oleh Tenenhaus et al. (2004) dalam Yamin dan Heri Kurniawan (2011). Nilai Goodness of Fit (GoF) index diperoleh dari average communalities index dikalikan dengan nilai $\mathrm{R}^{2}$ model. Nilai GoF terbentang antara 0-1 dengan interpretasi sebagai berikut:

GoF Kecil = 0,1

Goodness of Fit (GoF) GoF Moderat $=0,25$

Goodness of Fit (GoF) Gof Besar $=0,36$

Rumus Goodness of Fit (GoF) :

$$
\begin{aligned}
& \text { GoF } R I=\sqrt{\text { AVE } \times R^{2}} \\
& \text { GoF } R I=\sqrt{0,629 \times 0,788^{2}} \\
& \text { GoF RI= } \sqrt{0,629 \times 0,621} \\
& \text { GoF } R I=\sqrt{0,391} \\
& \text { GoF } R I=0.625
\end{aligned}
$$

Pada perhitungan Goodness of Fit (GoF) diatas menunjukkan hasilnya adalah untuk konstruk Repurchase Intention sebesar 0,625 (GoF Besar). Dari hasil tersebut bisa disimpulkan bahwa performa antara model pengukuran dan model struktural memiliki GoF yang besar yaitu sebesar 0,625 (melebihi $0,36)$.
Tabel 6. Hasil Pengujian Hipotesis (Estimasi Koefisien Jalur)

\begin{tabular}{lccc}
\hline \multicolumn{1}{c}{ Variabel } & $\begin{array}{c}\text { Original } \\
\text { Sample } \\
(\mathrm{O})\end{array}$ & $\begin{array}{c}\mathrm{T} \\
\text { Statistic } \\
\mathrm{s}\end{array}$ & Keterangan \\
\hline $\begin{array}{l}\text { Experiential Marketing } \\
\begin{array}{l}\text { Intepurchase } \\
\text { Intion }\end{array}\end{array}$ & 0.193 & 2.036 & $\begin{array}{c}\text { Positif - } \\
\text { Signifikan } \\
\text { Positif - }\end{array}$ \\
$\begin{array}{l}\text { Self Efficacy } \rightarrow \\
\text { Repurchase Intention } \\
\begin{array}{l}\text { Trust } \rightarrow \text { Repurchase } \\
\text { Intention }\end{array}\end{array}$ & 0.367 & 3.772 & $\begin{array}{c}\text { Signifikan } \\
\text { Positif - } \\
\text { Signifikan }\end{array}$ \\
\hline
\end{tabular}

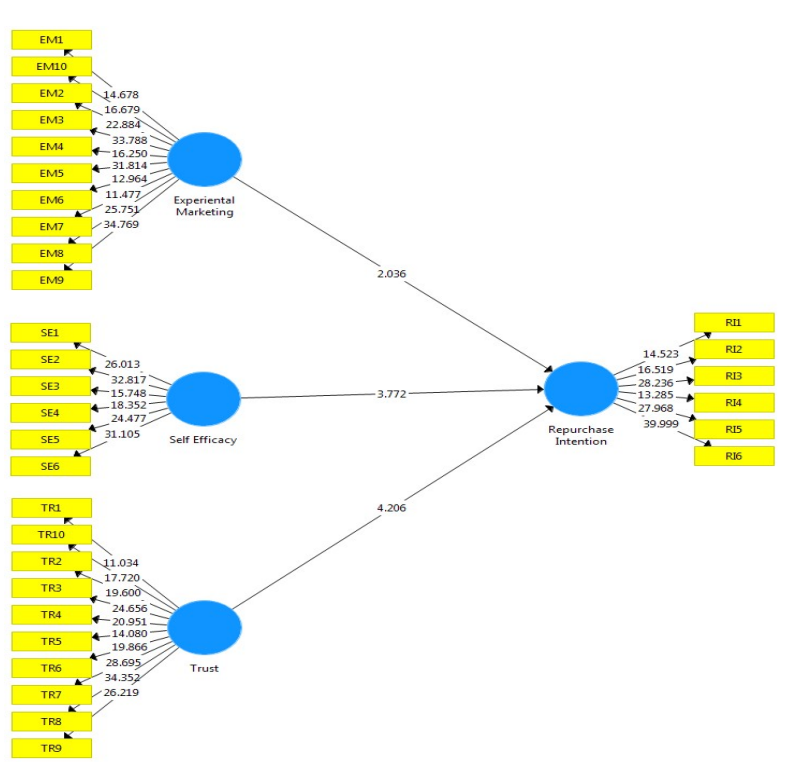

Gambar 3. Hasil Bootstrapping (Hasil Uji Hipotesis)

Berdasarkan Tabel 6 dan Gambar 3 menunjukan bahwa hubungan antara Experiential Marketing terhadap Repurchase Intention adalah signifikan dengan nilai tstatistic sebesar 2,036 (>1,96). Nilai original sample estimate adalah positif yaitu 0,193 yang menunjukan bahwa arah hubungan antara Experiential Marketing terhadap Repurchase Intention adalah positif. Jadi pada hipotesis H1 dalam penelitian ini dapat disimpulkan bahwa Experiential Marketing terhadap berpengaruh positif dan signifikan terhadap Repurchase Intention. Kemudian hubungan antara Self Efficacy terhadap Repurchase Intention adalah signifikan dengan nilai t-statistic sebesar 3,772 $(>1,96)$. 
Nilai original sample estimate adalah positif yaitu 0,367 yang menunjukan bahwa arah hubungan antara Self Efficacy terhadap Repurchase Intention adalah positif. Jadi pada hipotesis H2 dalam penelitian ini dapat disimpulkan bahwa Self Efficacy berpengaruh positif dan signifikan terhadap Repurchase Intention.

Hubungan antara Trust terhadap Repurchase Intention adalah signifikan dengan nilai t-statistic sebesar 4,206 $(<1,96)$. Nilai original sample estimate adalah positif yaitu 0,375 yang menunjukan bahwa arah hubungan antara Trust terhadap Repurchase Intention adalah positif. Jadi pada hipotesis H3 dalam penelitian ini dapat disimpulkan bahwa Trust berpengaruh positif dan signifikan terhadap Repurchase Intention.

\section{Pembahasan}

\section{Pengaruh Experiential Marketing terhadap Repurchase Intention}

Hipotesis pertama (H1) menyatakan bahwa terdapat pengaruh positif dan signifikan dalam hubungan Experiential Marketing terhadap Repurchase Intention. dengan hasil original sample sebesar 0,193 dan t-statstics sebesar 2,036 $(>1,96)$. Pada nilai koefisien jalur yang positif menunjukan hubungan yang searah, dimana adanya rasa pengalaman yang mengesankan terhadap responden untuk tetap memilih menggunakan Layanan Bus Premium Royaltrans dikarenakan pelayanan yang diberikan mampu menciptakan rasa aman dan nyaman, sehingga responden merasa tertarik untuk melakukan pembelian ulang dengan memanfaatkan fasilitas yang memadai yang diberikan oleh Layanan Bus Premium Royaltrans. Ini berarti Experiential Marketing yang dilakukan oleh Layanan Bus Premium Royaltrans terbukti berhasil disampaikan dengan baik, dimana dengan adanya fasilitas yang ditawarkan mampu mendorong responden untuk dapat tertarik menggunakan Layanan Bus Premium Royaltrans. Hal ini akan menumbuhkan motivasi untuk para pelanggan yang melakukan pembelian ulang secara kontinyu pada Layanan Bus Premium Royaltrans.

Hasil penelitan ini sesuai dan sejalan dengan penelitian yang dilakukan Wijaya A (2018) yang menyatakan adanya hubungan positif dan signifikan antara Experiential Marketing terhadap minat Repurchase Intention pada konsumen De Mandailing Cafe. Tetanoe, V.R (2014) juga melakukan penelitian yang menyebutkan bahwa adanya pengaruh positif yang signifikan antara Experiential Marketing terhadap minat beli ulang di Breadtalk Surabaya Town Square. Dengan kata lain jika dihubungkan dengan penelitian sebelumnya dapat dikatakan konsisten.

\section{Pengaruh Self Efficacy terhadap Repurchase Intention}

Hipotesis kedua (H2) menyatakan bahwa terdapat pengaruh positif dan signifikan dalam hubungan Self Efficacy terhadap Repurchase Intention, dengan hasil original sample sebesar 0,367 dan t-statstics sebesar $3,772(>1,96)$. Adapun nilai koefisien jalur yang positif menunjukan hubungan yang searah. Hal ini terlihat dengan adanya keinginan yang dirasakan oleh responden yang termemotivasi untuk melakukan pembelian ulang dalam menggunakan Layanan Bus Premium Royaltrans, selain itu hal ini membuktikan bahwa semakin tinggi manfaat yang didapatkan atau diterima maka akan menimbulkan respon positif dari pelanggan bahwa memilih Layanan Bus Premium Royaltrans sebagai sarana transportasi berpergian adalah hal yang efektif dan efisien seperti menghemat biaya, kemudahan melakukan transaksi pembelian bisa dengan tunai maupun cashless, mampu memberikan kenyamanan dan ketenangan dalam perjalanan serta terjamin keamanan selama perjalanan.

Hasil penelitian ini sejalan dengan penelitian Wulandari (2014) menguji mengenai Self Efficacy terhadap minat 
seseorang untuk berwirausaha pada siswa kelas XII SMK Negeri 1 Surabaya menunjukkan hasil yang positif dan signifikan. Penelitian ini bertujuan untuk menjelaskan bahwa pengaruh efikasi diri mampu mendorong seseorang untuk berwirausaha dan sebagai sarana pengembangan diri motivasi siswa. Bila diimplementasikan pada penelitian ini dapat disimpulkan bahwa pengaruh Efikasi Diri (Self Efficacy) mampu menarik konsumen untuk melakukan minat beli ulang (Repurchase Intention) pada Layanan Bus Premium Royaltrans. Dengan kata lain jika dihubungkan dengan penelitian sebelumnya dapat dikatakan konsisten.

\section{Pengaruh Trust terhadap Repurchase Intention}

Hipotesis kedua (H3) menyatakan bahwa terdapat pengaruh positif dan signifikan dalam hubungan Trust terhadap Repurchase Intention, dengan hasil original sample sebesar 0,375 dan t-statstics sebesar 4,206 (> 1,96).

Adapun nilai koefisien jalur yang positif menunjukan hubungan yang searah. Hal ini terlihat dengan adanya kepercayaan responden yang melakukan pembelian ulang Layanan Bus Premium Royaltrans, selain itu hal ini menunjukkan bahwa pelayanan yang optimal dengan menekankan nilai konsistensi, intergritas dan dan loyal terhadap konsumen akan memberi respon positif dari pelanggan untuk tetap menggunakan Layanan Bus Premium Royaltrans sebagai sarana transportasi. Maka dengan ini kepercayaan (Trust) dapat memberikan hasil yang positif dan signifikan terhadap Repurchase Intention.

Hasil penelitian ini sejalan dengan penelitian W Sari, I. D. P., Nobelson, N., \& Sembiring, R (2018) menguji mengenai Trust terhadap minat beli pada Lazada.co,id yang menunjukkan hasil yang positif dan signifikan. Bila diimplementasikan pada penelitian ini dapat disimpulkan bahwa pengaruh Trust mampu menarik konsumen untuk melakukan minat beli ulang (Repurchase Intention) pada Layanan Bus Premium Royaltrans. Thamizhvanan, A \& Xavier, M.J. (2013) juga melakukan penelitian yang menyebutkan bahwa adanya pengaruh positif yang signifikan antara Trust terhadap minat beli ulang pada pembelian online pada masyarakat india. Dengan kata lain jika dihubungkan dengan penelitian sebelumnya dapat dikatakan konsisten.

\section{SIMPULAN}

Experiential Marketing memiliki pengaruh positif dan signifikan terhadap Repurchase Intention pada studi kasus pelanggan Bus Royaltrans di Wilayah Bekasi. Hal ini membuktikan bahwa semakin tinggi Experiential Marketing atau pengalaman yang dirasakan maka semakin besar pula minat pembelian ulang serta hal ini juga mendorong terciptanya suatu sikap responden di wilayah Bekasi akan tetap kembali menggunakan Layanan Bus Premium Royaltrans karena Service Excellent yang dilakukannya, sehingga responden tetap memilih Royaltrans sebagai sarana transportasi harian. Hal ini akan memotivasi untuk para konsumen yang menggunakan untuk melakukan pembelian ulang karena fasilitas, keterjangkauan dan rasa aman yang diberikan Layanan Bus Premium Royaltrans secara optimal dapat memberikan keuntungan dan kepada konsumen misalnya dalam menghemat biaya dan bisa dengan tenang dan nyaman beristirahat. Self Efficacy memiliki pengaruh positif dan signifikan terhadap Repurchase Intention pada studi kasus pelanggan Bus Royaltrans di Wilayah Bekasi. Hal ini menunjukkan bahwa Self Efficacy atau efikasi diri mampu menciptakan motivasi, keyakinan dan komitmen kepada diri konsumen untuk tetap selalu menggunakan Layanan Bus Premium Royaltrans, selain itu hal ini membuktikan bahwa semakin tinggi manfaat yang diterima dan dirasakan oleh pengguna, maka akan menimbulkan respon 
postif dari konsumen bahwa memilih Layanan Bus Premium Royaltrans sebagai sarana transportasi harian adalah langkah yang efektif karena selain menguntungkan dan bermanfaat seperti terjaminnya rasa aman dan nyaman, mengurangi tingkat stress selama di perjalanan dan efisiensi waktu dan tenaga. Trust memiliki pengaruh positif dan signifikan terhadap Repurchase Intention pada studi kasus pelanggan Bus Royaltrans di Wilayah Bekasi. Hal ini membuktikan bahwa adanya suatu kepuasaan pelanggan yang telah menggunakan Layanan Bus Premium Royaltrans dan merekomendasikan Bus Royaltrans sebagai sarana transportasi kelas premium yang aman dan nyaman. Hal ini juga membawa dampak positif kepada Layanan Bus Premium Royaltrans, dimana bila tingkat kepuasan pelanggan bertambah dan menghasilkan customer loyalty, maka konsumen akan terus melakukan pembelian ulang Bus Royaltrans dan semakin sering pula konsumen tersebut merekomendasikan Layanan Bus Premium Royaltrans kepada orang lain yang akhirnya akan menambah jumlah calon pengguna rutin Layanan Bus Premium Royaltrans yang beralih dari yang dulunya menggunakan kendaraan pribadi kini beralih ke Layanan Bus Premium Royaltrans.

Beberapa saran yang dapat diberikan dari hasil penelitian bahwa layanan Bus Premium Royaltrans harus mengoptimalkan pelayanan dimana indikator nilai rata - rata terendah agar makin ditingkatkan. Pada variabel Experiential Marketing, menunjukkan bahwa indikator yang memiliki nilai rata - rata tertinggi adalah indikator Perilaku Individu (EM8) sebesar 4,481. Namun bila dilihat juga pada loading factor menunjukkan bahwa pada indikator Satisfaction (EM 5) sebesar 0,865, maka dengan ini indikator yang memiliki nilai tertinggi ini harus dipertahankan dan nilai rata - rata terendah adalah indikator Respon terhadap setiap masalah (EM7) sebesar 3,9. Hal ini juga sejalan pada hasil loading factor yang menunjukkan bahwa
Respon terhadap setiap masalah (EM7) yang mengarah pada hasil terendah sebesar 0,681. Maka dengan ini, indikator yang memiliki nilai terendah ini perlu ditingkatkan kembali respon terhadap setiap masalah di Layanan Bus Premium Royaltrans agar pelanggan makin merasa puas dan tetap menggunakan Layanan Bus Premium Royaltrans. Pada Variabel Self Efficacy, menunjukkan bahwa indikator yang memiliki nilai mean tertinggi adalah indikator Keyakinan terhadap kemampuan dalam mengambil tindakan yang diperlukan untuk mencapai hasil (SE1) sebesar 4,569. Namun bila dilihat juga pada loading factor menunjukkan bahwa indikator Memiliiki pandangan positif terhadap layanan yang digunakan (SE 2) sebesar 0,864, maka dengan ini indikator yang memiliki nilai tertinggi ini harus dipertahankan dan nilai rata - rata terendah adalah indikator Memiliki keyakinan diri yang kuat terhadap potensi diri (SE5) sebesar 4,031. Hal ini juga sejalan pada hasil loading factor yang menunjukkan bahwa Memiliki keyakinan diri yang kuat terhadap potensi diri (SE5) yang mengarah pada hasil terendah sebesar 0,784. Maka dengan ini, indikator yang memiliki nilai terendah ini perlu ditingkatkan kembali dan perlu adanya motivasi yang membangun kepada pengguna Layanan Bus Premium Royaltrans untuk selalu menggunakan layanan tersebut dan melakukan kegiatan sosialiasi, sharing session dan promosi untuk mendorong diri konsumen untuk terus menggunakan Layanan Bus Premium Royaltrans. Pada Variabel Trust, menunjukkan bahwa indikator yang memiliki nilai rata - rata tertinggi adalah indikator Kejujuran (TR1) sebesar 4,681. Namun bila dilihat juga pada loading factor menunjukkan bahwa indikator Keterampilan (TR 3) sebesar 0,866 , maka dengan ini indikator yang memiliki nilai tertinggi ini harus dipertahankan dan nilai rata - rata terendah adalah indikator Tepat Waktu (TR5) sebesar 3,91 . Hal ini juga sejalan pada hasil loading 
factor yang menunjukkan bahwa Tepat Waktu (TR5) yang mengarah pada hasil terendah sebesar 0,668, maka dengan ini, perlu ditingkatkan kembali ketetapan waktu pemberangkatan serta pengaturan waktu headway dan estimasi waktu perjalanan. Pada Variabel Repurchase Intention, menunjukkan bahwa indikator yang memiliki nilai rata rata tertinggi adalah indikator Merekomendasikan (RI5) sebesar 4,391. Namun bila dilihat juga pada loading factor menunjukkan bahwa indikator Sosial Media (TR 6) sebesar 0,852, maka dengan ini indikator yang memiliki nilai tertinggi ini harus dipertahankan dan maka dengan ini harus dipertahankan dan nilai rata - rata terendah adalah indikator Pencarian Informasi (RI1) sebesar 3,888. Hal ini juga sejalan pada hasil loading factor yang menunjukkan bahwa Pencarian Informasi (RI1) yang mengarah pada hasil terendah sebesar 0,717 , maka dengan ini, perlu ditingkatkan kembali penyampaian informasi kepada pelanggan agar pelanggan lebih mudah menerima informasi selama menggunakan Layanan Bus Premium Royaltrans.

Pada penelitian yang akan datang sebaiknya memperbanyak variabel-variabel yang akan diambil untuk diujikan, dari hasil penelitian ini menunjukkan variabel independen (Experiential Marketing), (Self Efficacy) dan (Trust) terhadap variabel dependen (Repurchase Intention) memberikan nilai R-square sebesar 0.788 yang dapat diinterpretasikan bahwa variabel konstruk Experiential Marketing, Self Efficacy dan Trust sebesar 78,8\% sedangkan 21,2\% dijelaskan oleh variabel lain di luar yang akan diteliti. Maka dengan ini, masih ada beberapa persentasi yang dapat dikaji kembali baik variabel independen maupun dependen yang tidak diketahui agar hasil penelitian lebih akurat, serta memperluas tempat penelitian agar mendapatkan hasil dari sudut pandang yang lebih luas. Sehingga akan banyak memberikan masukan yang membangun untuk Layanan Bus Premium Royaltrans.

\section{REFERENSI}

Bachtiar, Yusuf. 2018. Ini Data Penurunan Jumlah Kendaraan di Pintu Tol Bekasi Pasca Ganjil Genap Berlaku. http://jakarta.tribunnews.com/ diakses pada 28 Oktober 2018.

Badan Pusat Statistik (BPS). 2014. Statistik Komuter Jabodetabek (Hasil Survei Komuter Jabodetabek 2014). www. bps.go.id/ diakses pada 28 Oktober 2018.

Biro Komunikasi dan Informasi Publik. 2018. Kebijakan Lalin Tol Jakarta Cikampek Sudah Melalui Kajian Matang. http://www.depkes.go.id/ diakses pada 28 Oktober 2018.

Hutapea, Erwin. 2018. 7 Penyebab Tol Jakarta-Cikampek Sering Macet. https://properti.kompas.com/ diakses pada 28 Oktober 2018.

Katadata.co.id. 2018. Berapa Jumlah Penduduk Jakarta?. https://databoks.katadata.co.id/datapub lish/2018/01/24/berapa-jumlahpenduduk-jakarta diakses pada 28 Oktober 2018.

Dewi, K., Nas, S., \& Riadi, R. M. (2016). Faktor yang Mempengaruhi Perilaku Konsumen dalam Memutuskan Pembelian Android oleh Mahasiswa Fkip Universitas Riau. Jurnal Online Mahasiswa Fakultas Keguruan dan Ilmu Pendidikan Universitas Riau, 3(1), 1-10.

Hendarsono, G. (2013). Analisa pengaruh Experiential marketing terhadap minat beli ulang konsumen cafe buntos 99 Sidoarjo. Jurnal Strategi Pemasaran, 1(2), 1-8.

Kusdyah, Ike. 2012. Persepsi Harga, Persepsi Merek, Persepsi Nilai, dan Keinginan Pembelian Ulang Jasa Clinic Kesehatan (Studi Kasus Erha Clinic 


\section{Jurnal Ilmiah Manajemen dan Bisnis}

ISSN 1693-7619 (Print) I ISSN 2580-4170 (Online) | http://jurnal.umsu.ac.id/index.php/mbisnis

Surabaya). Jurnal

Manajemen

Pemasaran, 7(1), 25-32.

Pamudi, P., dan E. Suryani. 2018. Penerapan Sistem Dinamik dalam Intelligent Transport Systems (ITS) untuk Meningkatkan Efektifitas, Efisiensi dan Safety (Study Kasus Dinas Perhubungan Kota Surabaya). INFORM: Jurnal Ilmiah Bidang Teknologi Informasi dan Komunikasi, 3(1), 19-25.

Sari, I. D. P., Nobelson, N., \& Rosali Sembiring. 2017. Pengaruh Harga (Price), Kenyamanan Konsumen (Customer Convenience) Dan Kepercayaan (Trust) Terhadap Minat Beli Di Lazada. Co. Id. Isei Business And Management Review, 1(2) 73-78.

Schwarzer, R., Judith Bäßler, Patricia Kwiatek, Kerstin Schröder \& Jian Xin Zhang. 1997. The assessment of optimistic self-beliefs: comparison of the German, Spanish, and Chinese versions of the general self-efficacy scale. Applied Psychology, 46(1), 6988.

Solomon, M.R. (2015), Customer Behavior: Buying,Having, Being, Eleventh Edition, Pearson Global Edition, United States Of America

Suen, L. J. W., Huang, H. M., \& Lee, H. H. (2014). A comparison of convenience sampling and purposive sampling. $H u$ Li Za Zhi, 61(3), 105.

Sullivan, Y. W., and D. J. Kim. 2018. Assessing the effects of consumers' product evaluations and trust on repurchase intention in e-commerce environments. International Journal of Information Management, 39, 199219.

Tetanoe, Vinsensius Ronald dan Diah Aharmayanti. 2014. Pengaruh Experiental Marketing Terhadap Pembelian Ulang dengan Kepuasan Pelanggan Sebagai Variable
Intervening di Breadtalk Surabaya Town Square. Jurnal Manajemen Pemasaran Petra, 2(11) 1- 12.

Thamizhvanan, Arun dan M.J. Xavier. 2013. Determinant of Customers' Online Purchase Intention: an Empirical Study in India. Journal of Indian Business Research, 3(1) 17-31.

Wijaya, Anneke. dan Hartono Subagio. 2014.

Analisis Pengaruh Experiential

Marketing Terhadap Repeat Purchase

Dengan Customer Satisfaction

Sebagai

Marketing. Jurnal

Experiential

Pemasaran, 2(1) 1-9.

Wulandari, Suci. 2013. Pengaruh Efikasi Diri terhadap Minat Berwirausaha pada Siswa Kelas XII di SMK Negeri 1 Surabaya. Jurnal Pendidikan Tata Niaga (JPTN), Vol. 1(1). 